\title{
Intraspecific Variation in a Scorpionfly Newly Recorded from Texas and the State of Taxonomy of North American Panorpidae (Mecoptera)
}

\author{
Joshua R. Jones \\ Department of Entomology, Texas A\&M University, College Station, TX 77843-2475, USA \\ Correspondence should be addressed to Joshua R. Jones, doc.jones3000@tamu.edu \\ Received 17 February 2010; Accepted 12 April 2010 \\ Academic Editor: Michael S. Engel
}

Copyright ( $) 2010$ Joshua R. Jones. This is an open access article distributed under the Creative Commons Attribution License, which permits unrestricted use, distribution, and reproduction in any medium, provided the original work is properly cited.

\begin{abstract}
Panorpa vernalis Byers is recorded for the first time from Texas, and represents only the second species of Panorpa documented from the state. Intraspecific variations between the Texas specimens and Byers' original description are discussed. A synopsis of the principal modern keys for identification of North American Panorpa is provided, and an argument for a modern taxonomic review of the Panorpidae of North America is presented.
\end{abstract}

\section{Introduction}

Texas is the largest state within the continental United States. Its expanse, an area 773 miles (1244 kilometers) wide and 790 miles (1270 kilometers) long and covering 261,797 square miles (678,050 square kilometers), includes mountains, deserts, medium-elevation hill country, highand low-elevation plains, extensive drainages, and a long coastline, all products of a complex geologic history [1]. The diversity of these regions comprises a vast array of habitats with highly varied floras and faunas. In the east, pine forests predominate. Mixed oak grasslands occupy much of the central portions of the state, while sage and mesquite blend with a host of woody shrubs and grasses in the panhandle, west and south. Ranches and farmland dot this landscape, and riverine forests course throughout [2].

While some of Texas' geologic regions are contained completely within the political boundaries of the state, several, with their respective floras and faunas, extend into Texas from adjacent states and regions $[3,4]$. The latter distribution pattern ought to hold true for the scorpionfly genus Panorpa (Mecoptera: Panorpidae), a speciose taxon (84 North American species) [5] distributed broadly throughout the deciduous forests of eastern North America, from Quebec to Mexico and from the East Coast westward to at least Kansas and Oklahoma. However, despite the presence of abundant habitat ideal for scorpionflies in the eastern portions of Texas, prior to this paper only a single species of Panorpa had been recorded from the state, Panorpa nuptialis Gerstaecker [5]. This large and conspicuous species, sometimes referred to as "the Texas scorpionfly," is fairly widespread in the midwestern and southeast US, having been recorded in the fall in Alabama, Arkansas, Kansas, Louisiana, Mississippi, Missouri, Oklahoma, Texas, and northeastern Mexico [5].

Numerous species of Panorpa have been recorded from the three states that form the northern and eastern borders of Texas: Oklahoma, Arkansas, and Louisiana. No species of Panorpa have been recorded from New Mexico, which abuts the entire western U.S. border of Texas. From Oklahoma have been recorded: P. choctaw Byers and P. nuptialis; from Arkansas: P. anomala Carpenter, $P$. brauerei Carpenter, and $P$. capillata Byers; and from Louisiana: P. americana Swederus, $P$. anomala, $P$. lugubris Swederus, $P$. nuptialis, $P$. rupeculana Byers, and $P$. vernalis Byers [5]. Thus, it is highly unusual that no species of Panorpa beside nuptialis have previously been recorded in Texas, particularly near the state's northern and eastern borders. 


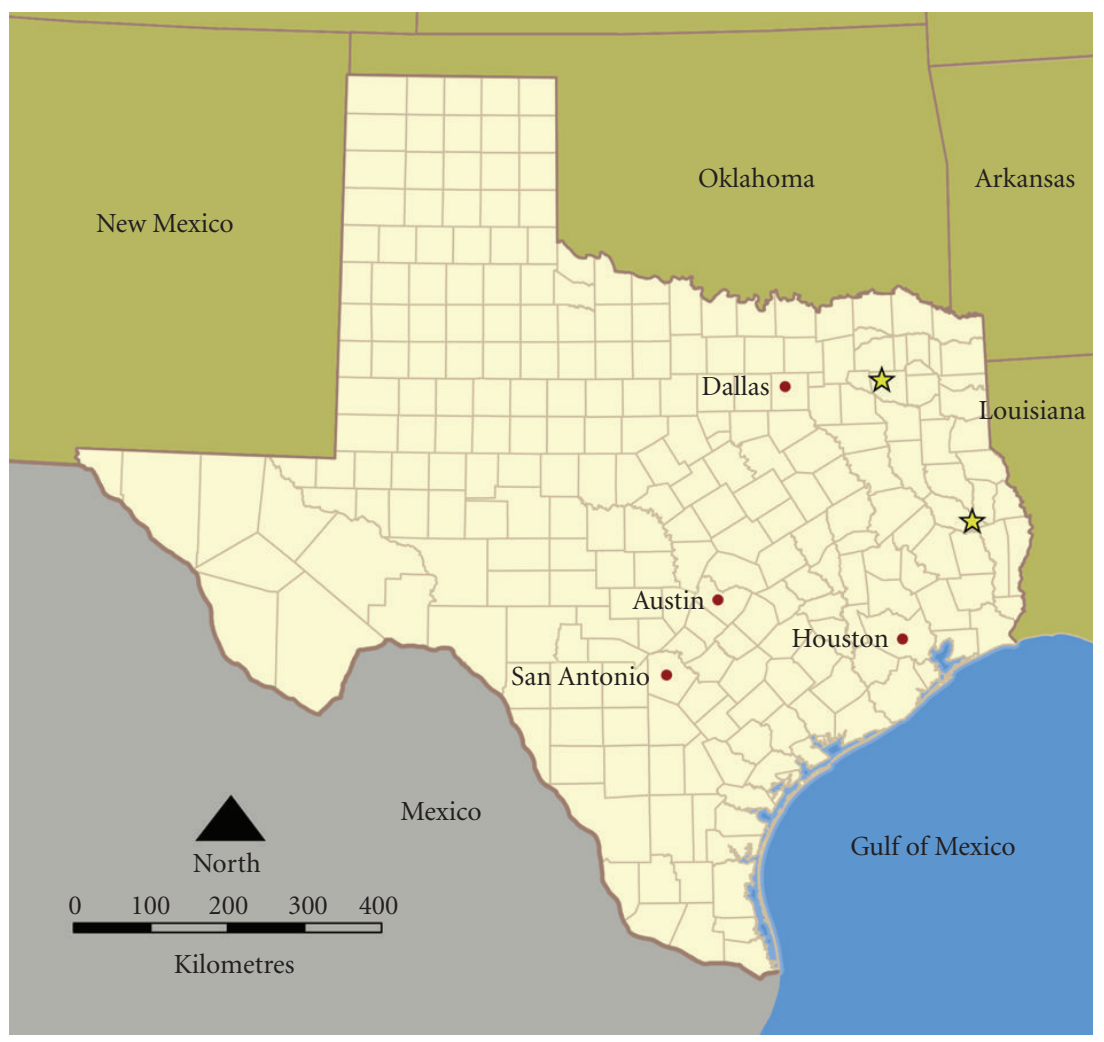

FIgure 1: Collection sites in Texas for Panorpa vernalis from material in the Texas A\&M Insect Collection. Sites are marked with yellow stars. The upper star corresponds to collection events 1-3 and the lower star to events 4-5 (see the appendix).

\section{Methods and Results}

During recent surveys of Mecoptera in the Texas A\&M University Insect Collection it was discovered that several short series of a Panorpa species new for Texas were deposited in the unsorted material. Panorpa vernalis Byers, a springemerging species known from Arkansas, Louisiana, and Mississippi, was collected from two counties in northeastern Texas. Three males and two females were collected from Angelina National Forest in Angelina Co., and two males and two females were collected from a private residence in Wood Co. All collections were made in March and April of 2000 and 2001, identified by W. Bicha in 2004, and reconfirmed by the author. A list of the specimens with their complete label information is provided in the appendix. A map displaying the collection sites can be seen in Figure 1.

\section{Intraspecific Variation}

The Texas specimens meet the morphological criteria laid out by Byers in his original description [6] for $P$. vernalis on most every point, but appear to exhibit variation in several aspects. For example, in Byers' illustrations of the male genitalia, the ventral paramere is displayed as being straight and its apex colinear with its stem, with the apicoventral barbs erect and slightly divergent. But in the Texas specimens, the apex of the paramere is strongly flexed dorsad, and the apicoventral barbs are compressed and convergent (Figure 2(a)). The ventral parameres are also slightly divergent from one another, rather than straight or slightly convergent as shown in Byers' illustration. One useful detail of the Texas material in making these evaluations is that except for a single specimen, all the males were critical-point dried, the soft tissues retain their shape and color exceptionally well and the sclerotized tissues are easily visualized. As a result, in one specimen from Wood Co., what appears to be an eversible sac is well preserved at the base of the base of the ventral parameres (not shown), and in the males a single pore is conspicuous in the center of the face of each ventral valve. Further, the fleshy nonsclerotized membranes are all a brilliant white color and have a very fine and subtle texture to them that may indicate glandular tissue. These features are usually obscured in dried pinned specimens. There does not appear to be a difference in the form of the ventral parameres as described above as a result of preparation technique, based on comparison of the single Texas male that was not criticalpoint dried with the specimens that were.

Regarding the maculation of the wings, Byers [6] stated that the "pattern of small dark spots [of the wings is] highly variable" but that "no bands or major spots [are] present". But in the Texas specimens, the remnants of the basal band (Byers does mention a few spots as being conserved, and at least one conforms to the basal band in the Texas specimens examined) can be seen along the anterior and posterior wing 


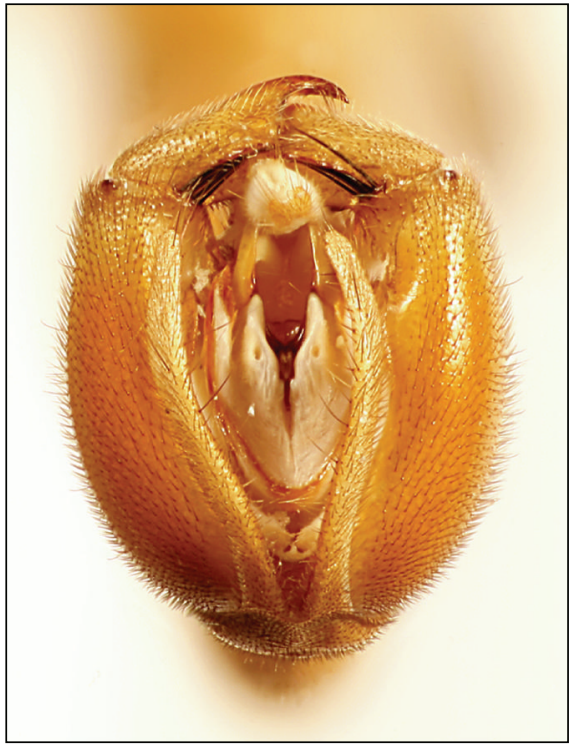

(a)

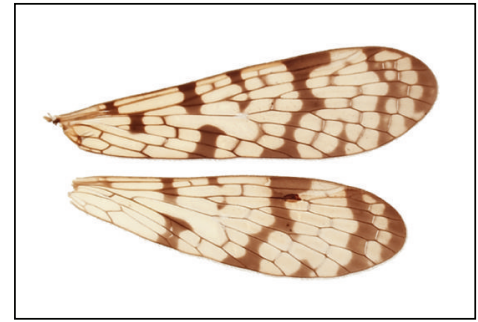

(b)

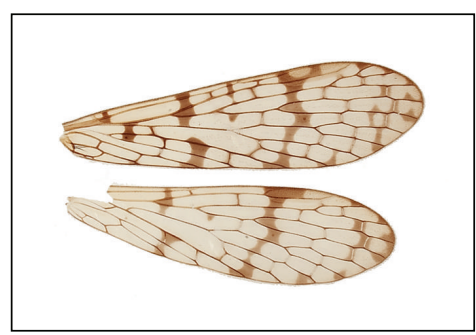

(c)

Figure 2: (a) Male genital bulb from Angelina Co. specimen demonstrating well preserved soft tissues, which appear white. The pores situated near the apices of the ventral valves can be seen clearly. (b)-(c) Wings of specimens of Panorpa vernalis from two counties in Texas displaying differences in expression of wing banding. (b) Specimen from Wood Co. (c) Specimen from Angelina Co.

margins in nearly every specimen, the marginal spot is often at least weakly expressed, the pterostigmal band is complete (see paragraph below) in all specimens, and extensive maculation in the area of the apical band is expressed in several specimens (Figures 2(b) and 2(c); see Byers [7] for wing maculation nomenclature). Further, Byers stated that "most crossveins [are] darkly margined", and his illustration displays a forewing with well expressed margining on nearly all crossveins. But in the Texas specimens, while some crossveins are margined, the level of expression of the margining in various portions of wing is highly inconsistent from specimen to specimen and from crossvein to crossvein such that the margining of almost no specimen resembles that in Byers illustration. In some Texas specimens, only the outer rank of crossveins are darkly margined, while in others, only the innermost or median ranks are darkly margined; in some specimens many crossveins are margined, but not darkly; and in others still, margining is not well expressed in any part of the wing. Thus it may not be possible to say confidently for all specimens of $P$. vernalis, that "most crossveins [are] darkly margined" [6].

Additional differences exist between the Wood Co. and Angelina Co. series. In the two Wood Co. males, only three stout black spines appear on the posteroventral margin of each basistyle, rather than five to six as in the Angelina Co. males and in Byers' description. There are also many differences in wing maculation. In all Wood Co. specimens (Figure 2(b)), the wing maculation is darker overall. The pterostigmal band is complete, slender and irregular, and the posterodistal branch is present but narrowly discontinuous, and obliquely spans two to three cells from the posterior margin. The pterostigmal maculation is dark, and eclipses the proximal half to three-fifths of the pterostigma, with no spot enclosed. In the Angelina Co. specimens (Figure 2(c)), the wing maculation is paler overall. The pterostigmal band is complete, very slender and irregular, and the posterodistal branch is only very poorly expressed at the posterior margin of the wing or absent altogether. The pterostigmal maculation is medium dark, eclipses the proximal half of pterostigma only, and in the forewings encloses a well defined pale spot (which represents a portion of the stigma). This spot varies in size between wings of individuals, and on one wing of a single female is very small.

These variations observed in the Texas specimens are likely simply regional phenomena, but may also suggest genetic isolation and the early to middle stages of ongoing speciation events. However, it is difficult to draw strong conclusions because of the relatively small number of specimens collected from each Texas county and because specimens from western Louisiana, Arkansas and adjacent regions were not available for direct comparison.

\section{Resources for Identification of North American Panorpa and the Current State of Taxonomy of North American Panorpidae}

The information presented here suggests that there is a need to sample Panorpidae more aggressively within Texas. It is possible that accelerated efforts to do so, particularly in the eastern regions, will yield additional new distribution records of species of Panorpa for the state.

These data also serve to reinforce the reality that much work remains to be done in regards to determining the geographic limits of many, if not nearly all, North American Panorpa species. There is no doubt that many gaps in the 


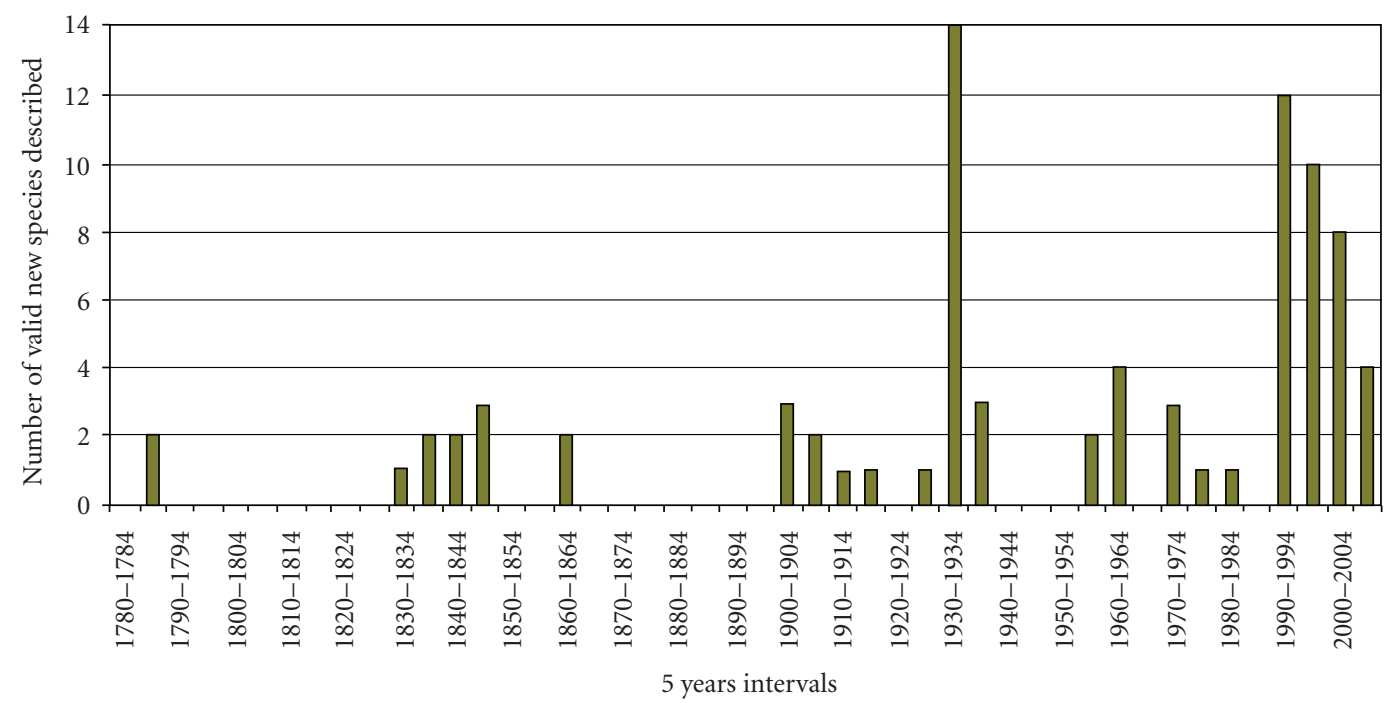

Figure 3: Progress in alpha-level taxonomy of North American Panorpa, 1780-2009. Since 1958, new species have been discovered at a rate of approximately nine every ten years.

distribution records for described species of North American Panorpa exist, and not only in Texas. The reasons for this are, primarily (1) the great void of expertise in the taxonomy of American Mecoptera that is being created as a result of the retirements of several important workers in the last decade or so; (2) the shortage of remaining knowledgeable workers (i) actively collecting scorpionflies in the field, (ii) making identifications of previously collected material retained in American natural history collections, and (iii) publishing new records from collections; and, perhaps most significantly, (3) the lack of a single, comprehensive, upto-date key to species of Panorpa of North America (the three hindrances identified above constitute a phenomenon commonly now referred to as the taxonomic impediment, which is hardly unique to the Mecoptera [8]). Instead, several separate regional keys of varying utility exist. The most recent key, by Cheung et al. [9], treats 13 northeastern Panorpa species whose distributions extend into Ontario. Byers, in 1996 [10], provided a key to 6 Mexican species in the involuta species group. Byers' 1993 [7] key to the autumnal Mecoptera covers 33 fall-emerging Panorpa species from the southeast U.S. but uncomfortably omits species known to emerge only in the spring/early summer. Webb et al. [11] treated 23 Midwestern species in their important work from 1975 on the Mecoptera of Illinois. The only other broad-ranging treatment of American Panorpa species of continued usefulness is Carpenter's 1931 [12] revision of the Nearctic Mecoptera, which includes two species of Panorpa not covered in more recent keys. Collectively, these keys cover the majority of American species, but not all-at least four U.S. and twenty-two Mexican species of the 84 valid North American species are not included.

The time appears to be ripe for a revision, or at least a comprehensive review, of the North American Panorpidae. In the last 50 or so years, dozens of American Panorpa species have been described $[6,7,10,13-22]$ at a relatively steady pace (ca. 9 species every ten years-see Figure 3), more than doubling-from 34-the number of species known at the time of the last major revision [12]. This indicates a possibility that at least some new species, perhaps those with more narrow distributions, yet remain to be discovered. Further, at present, no effort has been made to centralize knowledge of the recently described species, and descriptions are scattered throughout the literature. With the addition of all these new taxa it is clear that both a single, comprehensive, up-to-date key that treats the entire North American fauna, including the Mexican species, and a taxonomic synthesis summarizing modern knowledge of North American scorpionflies are now needed.

\section{Appendix}

\section{Specimens of Panorpa vernalis Byers in the Texas A\&M University Insect Collection}

Label data are in quotes, and individual labels are separated by three slashes ("///"). Collection event series one (1) through four (4) retain an additional label on their pin, not included below, that reads: "Panorpa vernalis Byers 1973, Det. W. Bicha 2004". Numbers of individuals in each series and their gender are given in italics.

(1) “TEXAS: Angelina Co., Angelina Nat'l. For., Jct. Big Creek \& USFS Rd. $302,31^{\circ} 5^{\prime} 18^{\prime \prime} \mathrm{N}, 94^{\circ} 19^{\prime} 14^{\prime \prime} \mathrm{W}$, III-24-2001, el. 70 m. /// Coll. J. B. Woolley, pan trap" 1 female.

(2) 'TEXAS: Angelina Co., Angelina Nat'l. For., Jct. Big Creek \& USFS Rd. $302,31^{\circ} 5^{\prime} 18^{\prime \prime} \mathrm{N}, 94^{\circ} 19^{\prime} 14^{\prime \prime} \mathrm{W}$, IV-6-2001, el. 70 m. /// Coll. R. S. Kirkpatrick, MV light" 2 males.

(3) "TEXAS: Angelina Co., Angelina Nat'l. For., Jct. Big Creek \& USFS Rd. $302,31^{\circ} 5^{\prime} 18^{\prime \prime} \mathrm{N}, 94^{\circ} 19^{\prime} 14^{\prime \prime} \mathrm{W}$, IV-30-31-2001, el. 70 m. /// Coll. R. S. Kirkpatrick, Malaise trap" 1 male, 1 female. 
(4) "TEXAS: Wood Co., Godwin Woods, 3.5 mi. SW

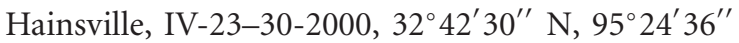
W, M. Yoder, yellow pan trap" 1 male, 2 females.

(5) "TEXAS: Wood Co., Godwin Woods, $3.5 \mathrm{mi} . \mathrm{E}$ Hainsville, IV-28-2000, $32^{\circ} 42^{\prime} 30^{\prime \prime} \mathrm{N}, 95^{\circ} 24^{\prime} 36^{\prime \prime} \mathrm{W}$, Coll. M. Yoder" 1 male.

\section{Acknowledgments}

The author thanks L. Somma for providing information on Texas Panorpa in the Florida State Collection of Arthropods and for his support on this project, and N. Penny and J. Oswald for their input on an early version of the manuscript.

\section{References}

[1] E. C. Alvarez and R. Plocheck, Eds., Texas Almanac 2010-2011, Texas State Historical Association, Denton, Tex, USA, 2009.

[2] R. G. Frye, K. L. Brown, and C. A. McMahan, "The vegetation types of Texas," Map. Texas Parks and Wildlife Department, 1984, http://www.tpwd.state.tx.us/publications/ pwdpubs/media/pwd_mp_e0100_1070n_34.pdf.

[3] Anonymous, "Natural subregions of Texas," in Preserving Texas' Natural Heritage, LBJ School of Public Affairs Policy Research Project Report 31, 1978, http://www.tpwd.state .tx.us/publications/pwdpubs/media/pwd_mp_e0100_1070x_34 .pdf.

[4] F. W. Gould, G. O. Hoffman, and C. A. Rechenthin, "Gould ecoregions of Texas," in Vegetational Areas of Texas, Leaflet No. 492, Texas A\&M University, Texas Agricultural Experiment Station, College Station, Tex, USA, 1960, http://www.tpwd.state.tx.us/publications/pwdpubs/media/ pwd_mp_e0100_1070ad_34.pdf.

[5] N. D. Penny and J. F. Parinas, World Checklist of Extant Mecoptera Species, California Academy of Sciences, San Francisco, Calif, USA, 1997, http://research.calacademy.org/ redirect?url=http://researcharchive.calacademy.org/research/ entomology/Entomology_Resources/Mecoptera/panorpa .htm.

[6] G. W. Byers, "Descriptions and distributional records of American Mecoptera. III," University of Kansas Science Bulletin, vol. 46, pp. 362-375, 1973.

[7] G. W. Byers, "Autumnal Mecoptera of Southeastern United States," The University of Kansas Science Bulletin, vol. 55, pp. 57-96, 1993.

[8] Q. D. Wheeler, P. H. Raven, and E. O. Wilson, "Taxonomy: Impediment or Expedient?" Science, vol. 303, no. 5656, p. 285, 2004.

[9] D. K. B. Cheung, S. A. Marshall, and D. W. Webb, "Mecoptera of Ontario," Canadian Journal of Arthropod Identification, no. $1,2006$.

[10] G. W. Byers, "Descriptions and distributional records of American Mecoptera. IV," University of Kansas Science Bulletin, vol. 55, pp. 519-547, 1996.

[11] D. W. Webb, N. D. Penny, and J. C. Marlin, "The Mecoptera, or scorpion-flies, of Illinois," Illinois Natural History Survey Bulletin, vol. 31, pp. 316-251, 1975.

[12] F. M. Carpenter, "Revision of the Nearctic Mecoptera," Bulletin of the Museum of Comparative Zoology, vol. 72, pp. 205-277, 1931.
[13] G. W. Byers, "Descriptions and distributional records of American Mecoptera," Journal of the Kansas Entomological Society, vol. 31, pp. 213-222, 1958.

[14] G. W. Byers, "Type specimens of Nearctic Mecoptera in European museums, including descriptions of new species," Annals of the Entomological Society of America, vol. 55, pp. 466476, 1962.

[15] G. W. Byers, "Descriptions and distributional records of American Mecoptera. II," The University of Kansas Science Bulletin, vol. 35, pp. 299-307, 1962.

[16] D. W. Webb, "New Species of Panorpa (Mecoptera: Panorpidae)," Entomological News, vol. 85, pp. 171-173, 1975.

[17] W. Bicha, "A new species of scorpionfly (Mecoptera: Panorpidae) from North Carolina," Proceedings of the Entomological Society of Washington, vol. 85, pp. 152-155, 1983.

[18] G. W. Byers, "Four puzzling new species of Mecoptera," Proceedings of the Entomological Society of Washington, vol. 99, no. 4, pp. 681-692, 1997.

[19] G. W. Byers, "Four new Mecoptera from Mexico," Journal of the Kansas Entomological Society, vol. 73, pp. 77-83, 2000.

[20] G. W. Byers, "New Mexican Mecoptera," Journal of the Kansas Entomological Society, vol. 74, pp. 92-100, 2001.

[21] G. W. Byers, "A new appalachian scorpionfly (Mecoptera: Panorpidae)," Journal of the Kansas Entomological Society, vol. 75, no. 3, pp. 185-187, 2002.

[22] W. Bicha, "New scorpionflies (Mecoptera: Panorpidae) from Jalisco, Michoacan, and Oaxaca, Mexico," Proceedings of the Entomological Society of Washington, vol. 108, no. 1, pp. 24-34, 2006. 

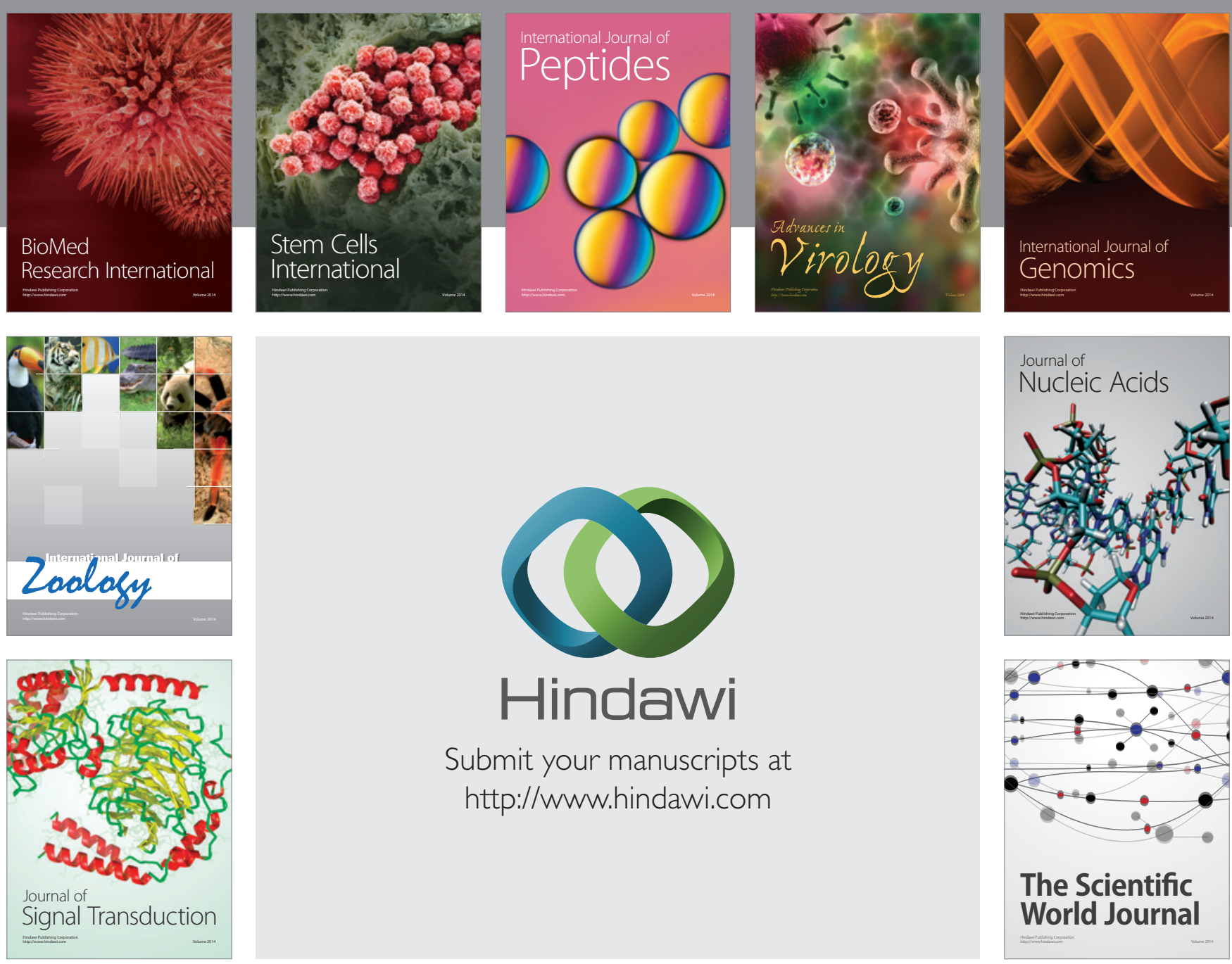

Submit your manuscripts at

http://www.hindawi.com
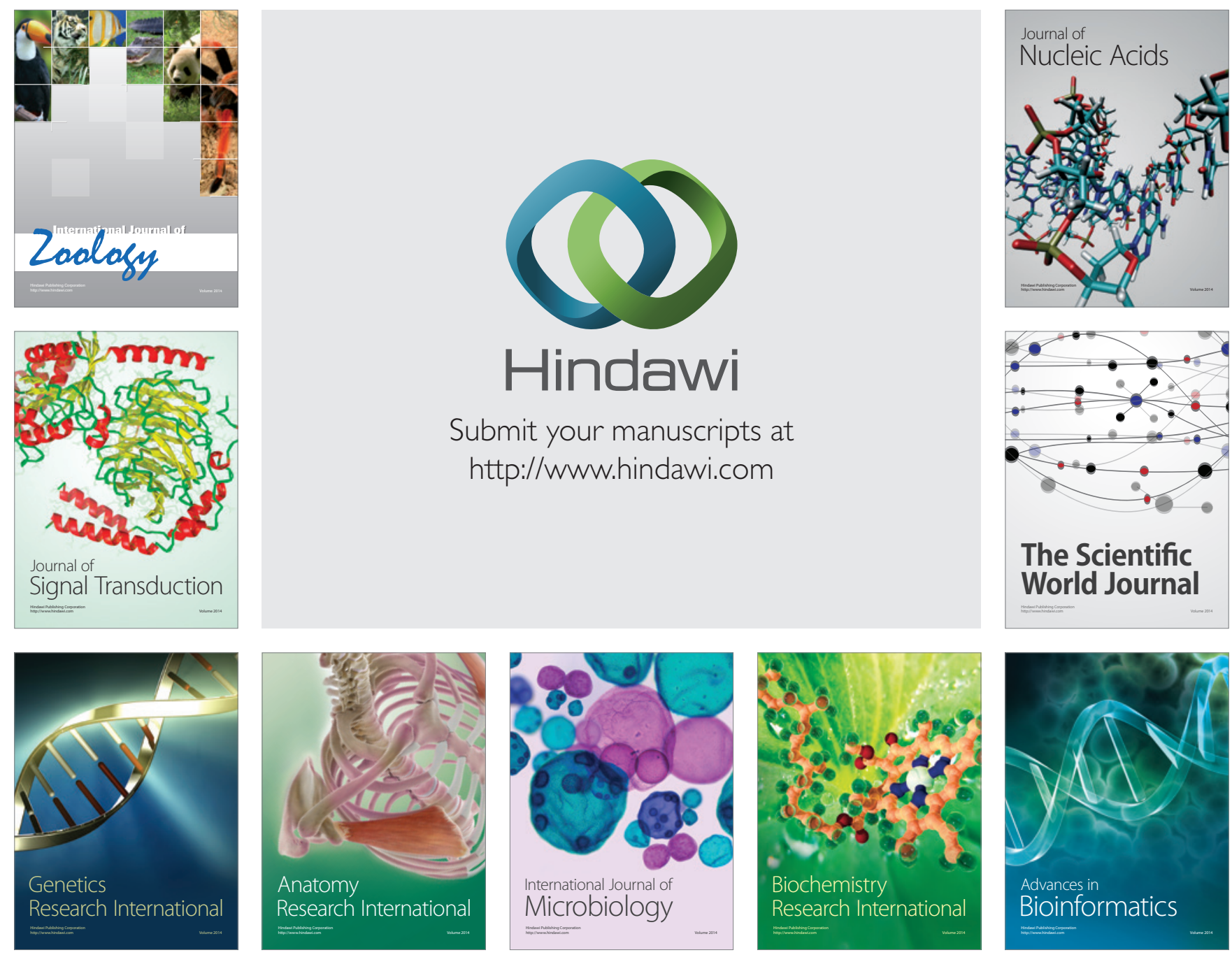

The Scientific World Journal
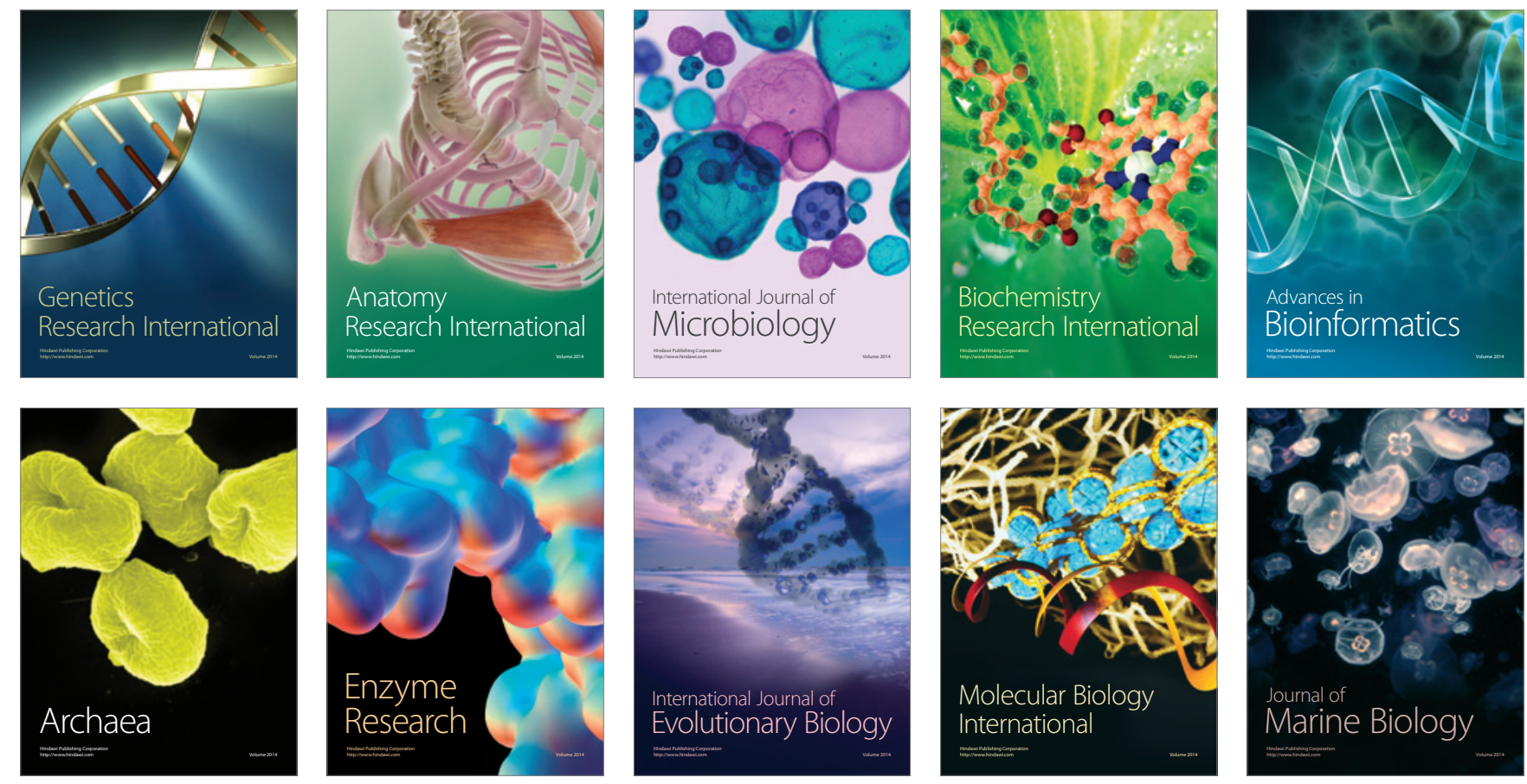